\title{
THE ANTIBACTERIAL ACTIVITY OF CERTAIN SANSEVIERIA THUNB. SPECIES AGAINST ESCHERICHIA COLI
}

\section{Tkachenko Halyna ${ }^{1}$, Buyun Lyudmyla ${ }^{2}$, Osadowski Zbigniew ${ }^{1}$, Maryniuk Myroslava ${ }^{2}$}

\author{
${ }^{1}$ Institute of Biology and Environmental Protection, Pomeranian University in Słupsk, Poland \\ ${ }^{2}$ M.M. Gryshko National Botanical Garden, National Academy of Science of Ukraine, Kyiv, Ukraine \\ Received 25. 6. 2017 \\ Revised 29. 6. 2017 \\ Published 30.11. 2017
}

The present study was aimed to investigate in vitro antimicrobial activity of ethanolic extracts of seventeen species of Sansevieria Thunb. genus (Sansevieria canaliculata Carrière, Sansevieria trifasciata Prain, Sansevieria cylindrica Bojer ex Hook., Sansevieria parva N.E.Br., Sansevieria fischeri (Baker) Marais, Sansevieria kirkii Baker, Sansevieria aethiopica Thunb., Sansevieria metallica Gérôme \& Labroy, Sansevieria caulescens N.E.Br., Sansevieria francisii Chahin., Sansevieria arborescens Cornu ex Gérôme \& Labroy, Sansevieria volkensii Gürke, Sansevieria forskaliana (Schult. \& Schult.f.) Hepper \& J.R.I.Wood, Sansevieria gracilis N.E.Br., Sansevieria hyacinthoides (L.) Druce, Sansevieria roxburghiana Schult. \& Schult.f., Sansevieria suffruticosa N.E.Br.) against Escherichia coli (ATCC 25922). The crude extracts were screened for antimicrobial activity using agar disk diffusion method. All the extracts showed variable degree of inhibition against tested bacterium. Therefore, the results revealed the antimicrobial potential of these extracts. In fact, the test organism was susceptible to extracts of Sansevieria kirkii, Sansevieria arborescens, Sansevieria roxburghiana, Sansevieria francisii, Sansevieria forskaliana, Sansevieria cylindrica, Sansevieria trifasciata, Sansevieria canaliculata, Sansevieria caulescens, Sansevieria metallica, Sansevieria aethiopica with diameters of inhibition zone from 12 to $24 \mathrm{~mm}$. Escherichia coli isolate was resistant only to S. hyacinthoides extract and the diameter of zone inhibition around the rest ranged from 8 to $10 \mathrm{~mm}$. Thus, the ethanolic extracts obtained from leaves of Sansevieria kirkii, Sansevieria arborescens, Sansevieria roxburghiana, Sansevieria francisii, Sansevieria forskaliana, Sansevieria cylindrica, Sansevieria trifasciata, Sansevieria canaliculata, Sansevieria caulescens, Sansevieria metallica, Sansevieria aethiopica possess antibacterial potency against Escherichia coli isolates and may be used as natural antiseptics and antimicrobial agents in medicine.

Keywords: Sansevieria; leaves extract; antimicrobial activity; paper disc diffusion method

\section{Introduction}

It was estimated that $70-80 \%$ of people worldwide rely chiefly on traditional, largely herbal; medicine to meet their primary healthcare needs (Farnsworth and Soejarto, 1991; Hamilton, 2004). The literature search on this issue has shown that Sansevieria Thunb., a genus with diverse ethnobotanical uses in its geographical distribution range, has occupy an important place among plant genera applied for treatment of a broad spectrum of diseases and disorders (Khalumba et al., 2005; Staples and Herbst, 2005; Takawira-Nyenya et al., 2014). During the last years, many Sansevieria 
species were screened and plants with high bioactive compounds were identified (Eze et al., 2011; Sheela et al., 2012; Adelanwa and Habibu, 2015).

Genus Sansevieria, belonging to Asparagaceae family (Lu and Morden, 2014), comprises ca. 70 species worldwide, distributed mainly in dry or arid areas of the Old World tropics and subtropics (Staples and Herbst, 2005), with a distribution range from Africa to south east Asia and the islands of the Indian Ocean (Alfani et al., 1989). Representatives of this genus are usually xerophytic perennial rhizomatous plants that occur in dry tropical and subtropical parts of the world (Staples and Herbst, 2005).

Africa is the center of diversity for Sansevieria (Carlquist and Schneider, 2007). Common English names for Sansevieria species are snake plant or bowstring-hemp, zebra lily, cow tongue, leopard lily, devil's tongue, good luck plant along with "mother-in-law's tongue" for the widely cultivated horticultural plant Sansevieria trifasciata (Staples and Herbst, 2005; Takawira-Nyenya et al., 2014).

The medicinal use of rhizomes and leaves of Sansevieria aethiopica is widespread within its native distribution range. For example, in southern Africa rhizomes and leaves of Sansevieria aethiopica are used to treat numerous health complaints, including ear-infections, toothache, hemorrhoids, stomach-ache, ulcer, diarrhea and internal parasites (Hedberg and Staugard, 1989). In Namibia Bushmen apply the heated, pounded leaves to a stiff neck to give relief. Leaf sap is applied to wounds to accelerate healing and to maternal breast to stimulate milk production. Rhizomes and leaves contain ruscogenin and related sapogenins, which have anti-inflammatory and venotomic properties. Nevertheless, antibacterial tests have given negative results (Brink and Achigan-Dako, 2012).

Futhermore, Sansevieria roxburghiana Schult. \& Schult.f. is taken as a remedy for coughs, rheumatism; as an expectorant, febrifuge, purgative, and tonic agents (Haldar et al., 2010). The study of Haldar and co-workers (2010) has demonstrated that the hydroalcoholic extract of Sansevieria roxburghiana rhizome exhibited remarkable antitumor activity against Ehrlich ascites carcinoma in Swiss mice that is speciously attributable to its augmenting endogenous antioxidant mechanisms. In addition, diethyl ether, alcohol, and acetone extracts of Sansevieria roxburghiana rhizome showed antibacterial activity against Escherichia coli, Pseudomonas aeruginosa, Klebsiella pneumoniae, and Staphylococcus aureus (Sheela et al., 2012).

The assessment of antimicrobial activity of the methanolic leaf extract of Sansevieria liberica, conducted by Adelanwa and Habibu (2015), has revealed that Bacillus cereus and Staphylococcus aureus were sensitive to the methanolic extract of Sansevieria liberica while Salmonella typhi and Escherichia coli were resistant to the extract (Adelanwa and Habibu, 2015). In addition, these authors carried out the phytochemical screening of Sansevieria liberica leaf extract, which demonstrated the presence of carbohydrate, triterpenes, flavonoids and cardiac glycosides; and, on the other hand, absence of anthraquinones and alkaloids in the plant. However tannins, saponins and steroids were found to be absent in Sansevieria liberica (Adelanwa and Habibu, 2015). These results are consistent with those of Eze and co-workers (2011), which have screened the antimicrobial activity of the leaf extract of Sansevieria liberica. Preliminary phytochemical assessment of the crude leaf extract and the fractions showed the presence of various bioactive substances such as alkaloids, saponins, flavonoids, terpenoids, steroids, and glycosides, reducing sugars, tannins, resins, carbohydrates, proteins, acidic compounds, fats and oils (Eze et al., 2011).

Although Escherichia coli can be an innocuous resident of the gastrointestinal tract, it also has the pathogenic capacity to cause significant diarrheal and extraintestinal diseases (Croxen et al., 2013). 
E. coli is a Gram-negative, oxidase-negative, rod-shaped bacterium from the family Enterobacteriaceae. It is able to grow both aerobically and anaerobically, preferably at $37^{\circ} \mathrm{C}$, and can either be nonmotile or motile, with peritrichous flagella. Pathogenic variants of Escherichia coli (pathovars or pathotypes) cause much morbidity and mortality worldwide (Croxen et al., 2013).

In addition, the development of bacterial resistance to presently available antibiotics has necessitated the search for new antimicrobial agents. Another challenging factor for the renewed interest in plant antimicrobial agents in the past 20 years has been the threatening rate of plant species extinction (Lewis and Elvin-Lewis, 1995).

Hence, an attempt has been made to evaluate antibacterial activity of seventeen species of Sansevieria genus against Escherichia coli. So the present study was conducted to investigate in vitro antimicrobial activity of ethanolic extracts of seventeen species of Sansevieria genus (Sansevieria canaliculata Carrière, Sansevieria trifasciata Prain, Sansevieria cylindrica Bojer ex Hook., Sansevieria parva N.E.Br. (syn. S. dooneri N.E.Br.), Sansevieria fischeri (Baker) Marais, Sansevieria kirkii Baker, Sansevieria aethiopica Thunb., Sansevieria metallica Gérôme \& Labroy, Sansevieria caulescens N.E.Br., Sansevieria francisii Chahin, Sansevieria arborescens Cornu ex Gérôme \& Labroy, Sansevieria volkensii Gürke (syn. S. intermedia N.E.Br.), Sansevieria forskaliana (Schult. \& Schult.f.) Hepper \& J.R.I.Wood, Sansevieria gracilis N.E.Br., Sansevieria hyacinthoides (L.) Druce (syn. S. grandis Hook.f.), Sansevieria roxburghiana Schult. \& Schult.f., Sansevieria suffruticosa N.E.Br.) against Escherichia coli strain.

\section{Materials and methodology}

\section{Collection of Plant Materials}

The leaves of Sansevieria plants, cultivated under glasshouse conditions, were sampled for antimicrobial potency assessment at M.M. Gryshko National Botanical Garden, National Academy of Science of Ukraine.

\section{Preparation of Plant Extracts}

Freshly collected leaves were washed, weighted, crushed, and homogenized in $96 \%$ ethanol (in proportion $1: 19$ ) at room temperature. Then the extracts were filtered and investigated for their antimicrobial activity. All extracts were stored at $4{ }^{\circ} \mathrm{C}$ until use.

\section{Bacterial test strain and growth conditions}

For this study, a strain of E. coli (ATCC 25922) was used. The cultivation medium was trypticase soy agar (Oxoid, UK), supplemented with $10 \%$ defibrinated sheep blood. Cultures were grown aerobically for $24 \mathrm{~h}$ at $37^{\circ} \mathrm{C}$. The cultures were later diluted with sterile solution of $0.9 \%$ normal saline to approximate the density of 0.5 McFarland standard. The McFarland standard was prepared by inoculating colonies of the bacterial test strain in sterile saline and adjusting the cell density to the specified concentration.

\section{Determination of antibacterial activity of plant extracts by the disk diffusion method}

Antimicrobial activity was determined using the agar disk diffusion assay (Bauer et al., 1966). Culture of Escherichia coli was inoculated onto Mueller-Hinton $(\mathrm{MH})$ agar plates. Sterile filter paper discs impregnated with extracts were applied over each of the culture plates. Isolates of bacterium were then incubated at $37^{\circ} \mathrm{C}$ for $24 \mathrm{~h}$. The plates were then observed for the zone of inhibition produced by the antibacterial activity of ethanolic extracts obtained from leaves of various Sansevieria species. As negative control disc impregnated with sterile ethanol was used in each experiment. At the end 
of the period, the inhibition zones formed were measured in millimeters using the Vernier calliper. For each extract, six replicates were assayed. The plates were observed and photographs were taken. Zone diameters were determined and averaged.

\section{Statistical analysis}

All statistical calculations were performed on separate data from each species (Statistica 8.0, StatSoft, Poland). The following zone diameter criteria were used to assign susceptibility or resistance of bacteria to the phytochemicals tested: Susceptible $(S) \geq 15 \mathrm{~mm}$, Intermediate $(I)=11-14 \mathrm{~mm}$, and Resistant $(R) \leq 10 \mathrm{~mm}$ (Okoth et al., 2013).

\section{Results and discussion}

The results of antimicrobial activity of ethanolic extracts obtained from leaves of Sansevieria species are presented in Figure 1 and 2.

Extracts from the leaves of Sansevieria kirkii and Sansevieria arborescens were particularly active against tested organism (diameters of inhibition zones were 24 and $22.5 \mathrm{~mm}$, respectively). It was followed by the activities of extracts derived from the leaves of Sansevieria roxburghiana, Sansevieria francisii, Sansevieria forskaliana, Sansevieria cylindrica, Sansevieria trifasciata, Sansevieria canaliculata, Sansevieria caulescens, Sansevieria metallica, Sansevieria aethiopica (diameters of inhibition zones were ranged within 12.0-13.5 mm). Finally, the ethanolic extracts of Sansevieria gracilis, Sansevieria suffruticosa, Sansevieria fischeri, and Sansevieria hyacinthoides showed less expressed antimicrobial activities (diameters of inhibition zones ranged from 8 to $11.5 \mathrm{~mm}$ ) (Figure 1 and 2).

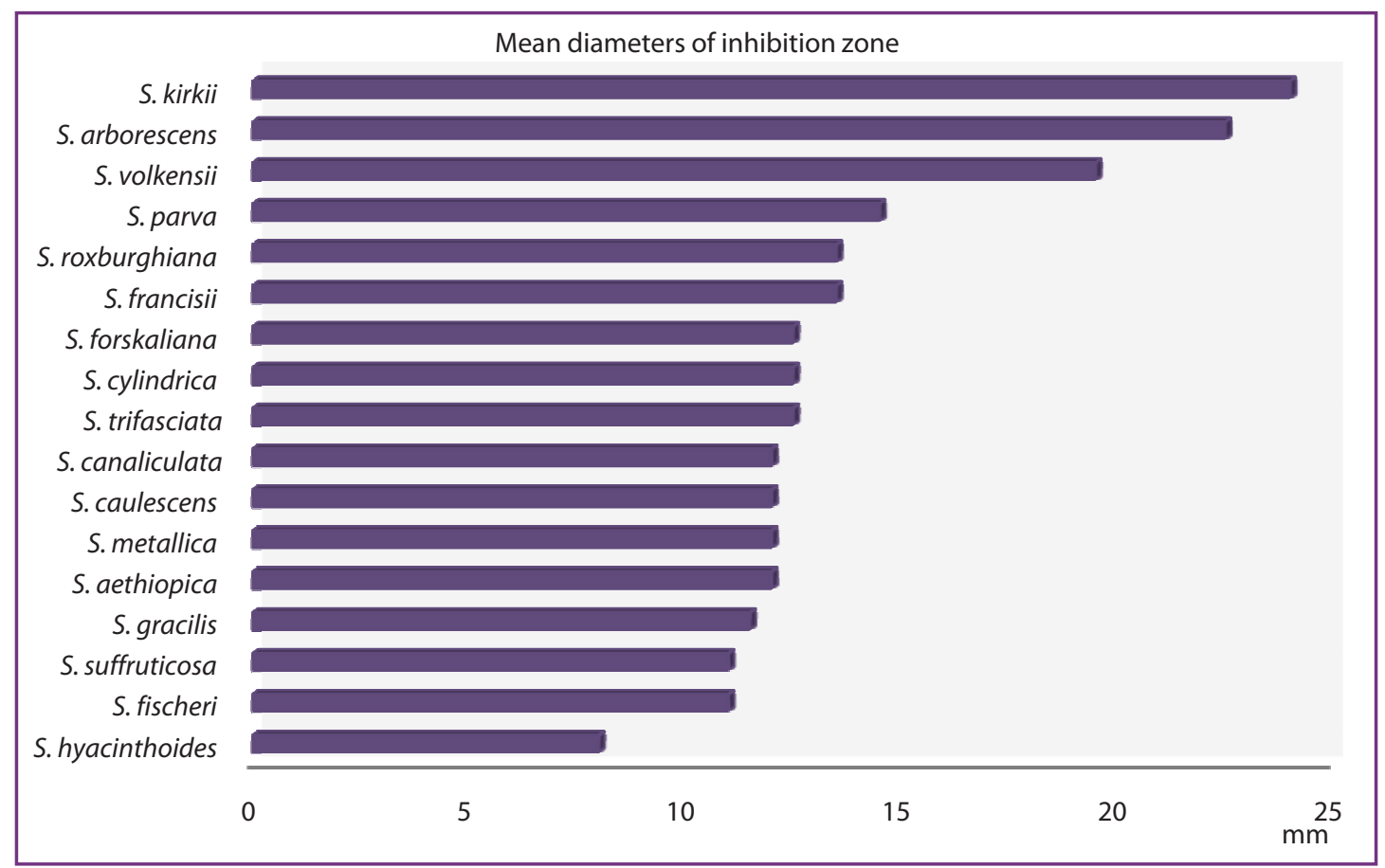

Figure 1 The diameters of inhibition zone produced by the ethanolic extracts obtained from leaves of Sansevieria species against Escherichia coli strain $(n=6)$ 

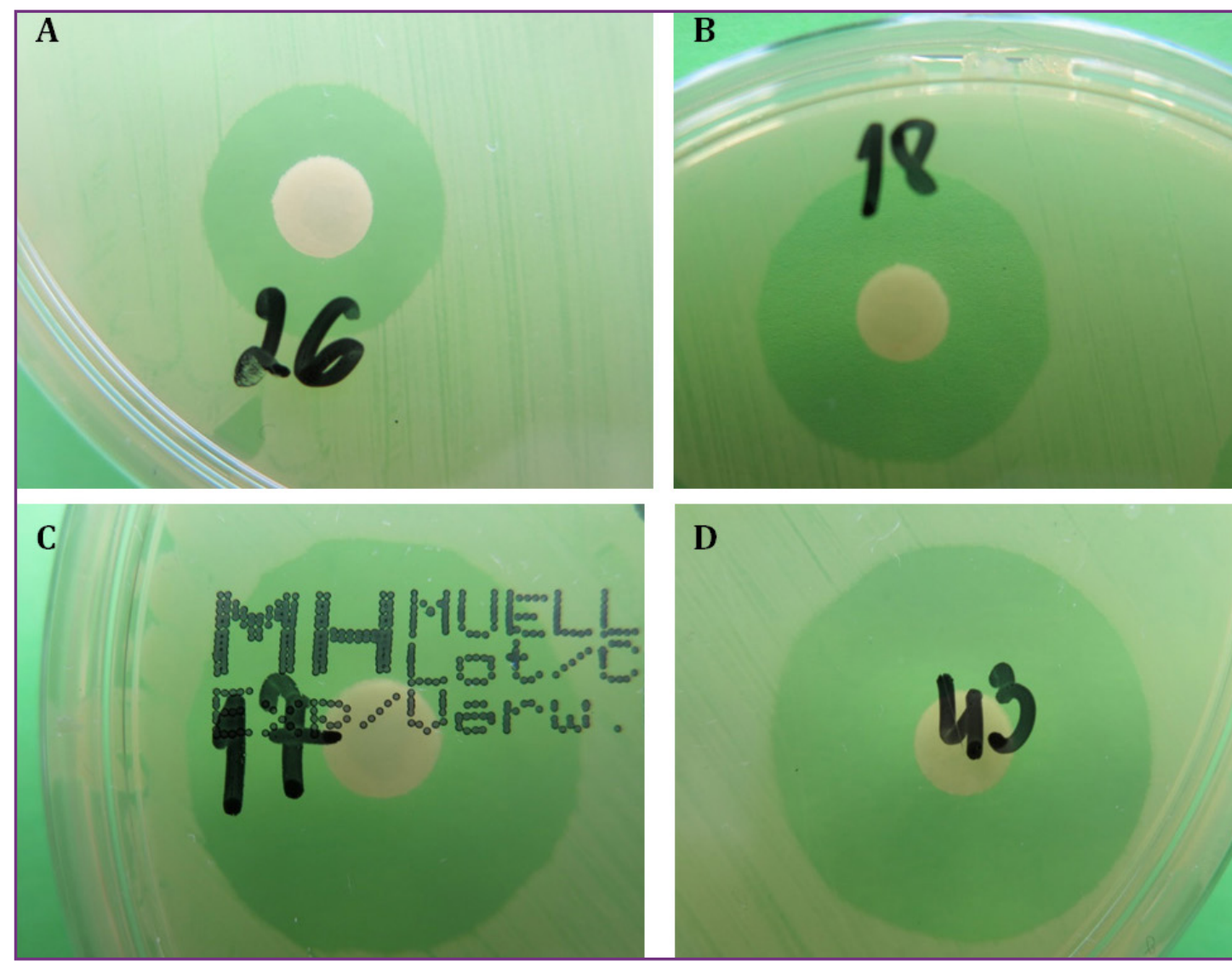

Figure 2 Antibacterial activity of the ethanolic extract obtained from the leaves of Sansevieria parva N.E.Br. (A), Sansevieria volkensii Gürke (B), Sansevieria arborescens Cornu ex Gérôme \& Labroy (C), and Sansevieria kirkii Baker (D) against Escherichia coli strain

The practice of traditional herbal medicine is widespread and plant-derived medicines are widely used for effective infectious disease treatment (Salehzadeh et al., 2014). The investigation of antimicrobial activity carried out in this study involved the determination of the sensitivity pattern of Escherichia coli to the leaf extracts of seventeen species of Sansevieria genus. The results revealed the antimicrobial potential of these extracts. The test organism was susceptible to extracts of Sansevieria kirkii, Sansevieria arborescens, Sansevieria roxburghiana, Sansevieria francisii, Sansevieria forskaliana, Sansevieria cylindrica, Sansevieria trifasciata, Sansevieria canaliculata, Sansevieria caulescens, Sansevieria metallica, Sansevieria aethiopica with inhibition zone diameter within 12-24 mm. Escherichia coli isolate was resistant only to Sansevieria hyacinthoides extract and the diameter of inhibition zone around the rest ranged from 8 to $10 \mathrm{~mm}$.

In agreement with the results obtained from the present study, previous research papers documented the noticeable antimicrobial potency of the ethanolic extracts from Sansevieria fischeri, Sansevieria francisii, Sansevieria parva, Sansevieria kirkii, Sansevieria aethiopica, Sansevieria caulescens, and Sansevieria metallica against Staphylococcus aureus (Deepa et al., 2011). The microbial growth inhibition capacity was attributed to the presence of the rich variety of phytochemicals including carbohydrates, saponin, flavonoids, phenols, alkaloid, anthocyanin and cyanine, glycosides, proteins 
and phytosterols (Deepa et al., 2011). According to Deepa and co-workers (2011), the methanolic and acetone extracts of leaves of S. roxburghiana showed antibacterial activity against Gram-positive bacteria such as Micrococcus luteus, Bacillus cereus, Enterococcus spp., Staphylococcus aureus, Gramnegative bacteria such as Proteus vulgaris, Pseudomonas aeruginosa, Pseudomonas fluorescense, Salmonella typhi, Salmonella paratyphi, Klebsiella pneumoniae, Shigella sonnie, and Escherichia coli, fungal strains Cryptococcus spp. and Candida albicans (Deepa et al., 2011). Ethyl acetate extracts of rhizomes also exhibited appreciable antimicrobial activity against most of the pathogens tested. The minimum inhibitory concentrations (MIC) of the various extracts by agar dilution method ranged from 1.0 to $8.0 \mathrm{mg}$ per $\mathrm{mL}$. The leaf extracts exhibited better antimicrobial activity than rhizomes (Deepa et al., 2011).

In our previous study (Buyun et al., 2016), we have evaluated the antibacterial capacity of ten species of Sansevieria genus against Staphylococcus aureus in order to validate scientifically the inhibitory activity for microbial growth attributed by their popular use and to propose new sources of antimicrobial agents. The selected bacterial strain Staphylococcus aureus is wide spread and causes serious problems due to its pathogenicity and high levels of drug resistance. The results proved that diameters of inhibition zones ranged from 16 to $34 \mathrm{~mm}$. Extracts from the leaves of Sansevieria fischeri and Sansevieria francisii were particularly active against tested organism (diameters of inhibition zones were $34 \mathrm{~mm}$ ). This was followed by the activities of extracts derived from the Sansevieria parva, Sansevieria kirkii, Sansevieria aethiopica, Sansevieria caulescens, Sansevieria metallica leaves (diameters of inhibition zones were ranged between 25 to $31 \mathrm{~mm}$ ). The ethanolic extracts of Sansevieria canaliculata and Sansevieria trifasciata showed less antimicrobial activities (diameters of inhibition zones were ranged between 16 to $16.5 \mathrm{~mm}$ ). The results proved that the ethanolic extracts from Sansevieria fischeri, Sansevieria francisii, Sansevieria parva, Sansevieria kirkii, Sansevieria aethiopica, Sansevieria caulescens, Sansevieria metallica exhibit a favorable antibacterial activity against Staphylococcus aureus (Buyun et al., 2016).

In the study conducted by Poonam Sethi (2013), the ethanolic extract of rhizome of Sansevieria roxburghiana plant displayed remarkable antibacterial activity against the four pathogenic bacteria, Salmonella typhi, Pseudomonas fluorescens, Pseudomonas aeruginosa, and Escherichia coli. Maximum activity was seen in the case of Pseudomonas fluorescens where the zone inhibition diameter was $32 \mathrm{~mm}(300 \mu \mathrm{g} / \mathrm{ml})$. The MIC study revealed that the value for the Salmonella typhi and Escherichia coli as 80 and $60 \mu \mathrm{g} / \mathrm{ml}$ for Pseudomonas fluorescens and Pseudomonas aeruginosa (Poonam Sethi, 2013). Hanumanth Kumar and Pramoda Kumari (2015) reported about potential bioactive secondary metabolites and revealed the possible antimicrobial activities of leaf extracts of Sansevieria roxburghiana. Antimicrobial screening revealed significant antimicrobial activity against Proteus vulgaris, Salmonella typhi, Pseudomonas aeruginosa, Klebsiella pneumoniae, and Escherichia coli (Hanumanth Kumar and Pramoda Kumari, 2015). Qualitative analysis, conducted by these authors, confirmed the presence of various primary and secondary plant metabolites such as alkaloids, terpenoids, flavonoids, saponins, steroids, phenols, tannins, and quinine in selected parts of Sansevieria roxburghiana.

S. roxburghiana also exhibited good inhibition effect against Staphylococcus aureus and $P$. aeruginosa whereas S. trifasciata manifested good antimicrobial effect against Escherichia coli, Staphylococcus aureus and Pseudomonas aeruginosa. It is interesting to note that the combined effect of antibiotics and plant extract has enhanced the antimicrobial effect of the extracts obtained against pathogenic microorganisms. The percentage inhibition of combined effect was calculated 
and it was observed that the leaves of S. roxburghiana possess antimicrobial effect (50\%) against Staphylococcus aureus combined with norfloxacin whereas the leaf extract of S. trifasciata when combined with tetracycline it showed $36 \%$ of inhibition against Staphylococcus aureus. The methanolic extract from the leaves of S. roxburghiana and S. trifasiata was effective against Gram-positive and Gram-negative pathogenic microorganisms. The $50 \mathrm{mg}$ per $\mathrm{mL}$ of the methanolic extracts manifested effective antimicrobial effect against pathogens (Kingsley et al., 2013).

Also, the results obtained from the present research showed antimicrobial potential of eleven extracts obtained from leaves of Sansevieria genus against Escherichia coli. So, these plants extracts can be used as antiseptics and antimicrobial agents in medicine. The antibacterial activity in Sansevieria genus may be due to presence of alkaloids, saponins, terpenoids, steroids, glycosides, tannins, acidic compounds, fats and oils in their composition. Also flavonoids have several therapeutic effects such as antioxidant and anti-inflammatory (Akindele et al., 2015).

\section{Conclusions}

To summarize, our findings demonstrate that the ethanolic extracts obtained from leaves of Sansevieria kirkii, Sansevieria arborescens, Sansevieria roxburghiana, Sansevieria francisii, Sansevieria forskaliana, Sansevieria cylindrica, Sansevieria trifasciata, Sansevieria canaliculata, Sansevieria caulescens, Sansevieria metallica, Sansevieria aethiopica possess antibacterial potency against Escherichia coli strain. Thus, the present study suggested that plant extracts which proved to be potentially effective can be used as a natural antiseptics and antimicrobial agents in medicine. Detailed research is required aimed at finding out mode of action of bioactive compounds of various Sansevieria species that are responsible for the documented antimicrobial efficacy.

In conclusion, we would like to emphasize that taking into account rapid losses and degradation of natural habitats in the tropics and associated with them catastrophic declines of many plant species populations, including Sansevieria spp., maintenance of living plants collection ex situ and assessment of their medicinal properties are very important.

\section{References}

Adelanwa, E.B., Habibu, I. 2015. Phytochemical screening and antimicrobial activities of the methanolic leaf extract of Jacaranda mimosifolia D. Don and Sansevieria liberica Thunb. Journal of Tropical Biosciences, vol. 10, p. 1-6.

Akindele, A.J., Wani, Z.A., Sharma, S., Mahajan, G., Satti, N.K., Adeyemi, O.O., Mondhe, D.M., Saxena, A.K. 2015. In vitro and in vivo Anticancer Activity of Root Extracts of Sansevieria liberica Gerome and Labroy (Agavaceae). Evid. Based Complement. Alternat. Med., vol. 2015, p. 11. DOI: 10.1155/2015/560404

Alfani, A., Ligrone, R., Fioretto, A., Virzo de Santo, A. 1989. Histochemistry, ultrastructure and possible significance of dead parenchyma cells with specialized walls in the leaf and rhizome of Sansevieria. Plant Cell and Environment, vol. 12, p. 249-259. DOI: 10.1111/j.1365-3040.1989.tb01939.x

Bauer, A.W., Kirby, W.M., Sherris, J.C., Turck, M. 1966. Antibiotic susceptibility testing by a standardized single disk method. Am. J. Clin. Pathol., vol. 45, no. 4, p. 493-496.

Brink, M., Achigan-Dako, E.G. 2012. Plant resources of tropical Africa. 16. Fibres. Netherlands, Source Wageningen: PROTA Foundation/CTA.

Buyun, L., Tkachenko, H., Osadowski, Z., Maryniuk, M. 2016. Antibacterial activity of certain Sansevieria species against Staphylococcus aureus. Słupskie Prace Biologiczne, vol. 13, p. 19-36.

Carlquist, S., Schneider, E.L. 2007. Origins and nature of vessels in monocotyledons. 9. Sansevieria. South African Journal of Botany, vol. 73. p. 196-203. DOI: 10.1016/j.sajb.2006.11.002. 
Croxen, M.A., Law, R.J., Scholz, R., Keeney, K.M., Wlodarska, M., Brett, B. 2013. Recent Advances in Understanding Enteric Pathogenic Escherichia coli. Clin. Microbiol. Rev., vol. 26, no. 4, p. 822-880. DOI: 10.1128/CMR.00022-13

Deepa, P., Kaleena, P.K., Valivittan, K., Girish Kumar, C.P. 2011. Phytochemical Screening and Antimicrobial Activity of Sansevieria roxburghiana Schult. and Schult. f. Middle-East Journal of Scientific Research, vol. 10, no. 4, p. 512-518.

Eze, C.C., Inya-Agha, S.I., Ezugwu, C.O., Ezea, S.E. 2011. Antimicrobial Activities of the Leaf Extract of Sansevieria liberica Ger. and Labr. (Fam: Dracaenaceae). African Journal of Pharmaceutical Research \& Development, vol. 3, no. 1, p. 14. DOI: 10.1016/S1995-7645(11)60195-8

Farnsworth, N.R., Soejarto, D.D. 1991. Global importance of medicinal plants. Akerele O., Heywood V. and Synge H. (eds.) The Conservation of Medicinal Plants. Cambridge University Press, Cambridge, UK, p. 25-51.

Haldar, P.K., Kar, B., Bhattacharya, S., Bala, A., Kumar, S.R.B. 2010. Antidiabetic activity and modulation of antioxidant status by Sansevieria roxburghiana rhizome in streptozotocin-induced diabetic rats. Diabetologia Croatica, vol. 39, no. 4, p. 115-123.

Hamilton, A.C. 2004. Medicinal plants, conservation and livelihoods. Biodiversity and conservation, vol. 13, p. 1477-1517.

Hanumanth Kumar, G., Pramoda Kumari, J. 2015. Phytochemical analysis of secondary metabolites and antimicrobial activity of Sansevieria roxburghiana. World Journal of Pharmaceutical Research, vol. 4, no. 2, p. 1072-1077.

Hedberg, I., Staugard, F. 1989. Traditional medicinal plants: Traditional medicine in Botswana. Gaborone: Ipeleng publishers, Broadhurst.

Khalumba, M.L., Mbugua, P.K., Kung'u, J.B. 2005. Uses and conservation of some highland species of the genus Sansevieria Thunb. in Kenya. African Crop Science Conference Proceedings, Uganda, vol. 7, p. 527-532.

Kingsley, D., Chauhan, R., Sinha, P., Abraham, J. 2013. Screening and Characterization of Antimicrobial Agents from Sansevieria roxburghiana and Sansevieria trifasciata. Asian Journal of Plant Sciences, vol. 12, no. 5, p. 224-227. DOI: 10.3923/ajps.2013.224.227

Lewis, W.H., Elvin-Lewis, M.P. 1995. Medicinal plants as sources of new therapeutics. Annals of the Missouri Botanical Garden, vol. 82, no. 1, p. 16-24. DOI: 10.2307/2399976

Lu, P.-L., Morden, C. 2014. Phylogenetic relationships among Dracaenoid genera (Asparagaceae: Nolinoideae) inferred from chloroplast DNA loci. Systematic Botany, vol. 39, no. 1, p. 90-104. DOI: 10.1600/036364414X678035

Okoth, D.A., Chenia, H.Y., Koorbanally, N.A. 2013. Antibacterial and antioxidant activities of flavonoids from Lannea alata (Engl.) Engl. (Anacardiaceae). Phytochem. Lett., vol. 6, p. 476-481. DOI: 10.1016/j. phytol.2013.06.003

Salehzadeh, A., Asadpour, L., Naeemi, A.S., Housmand, E. 2014. Antimicrobial activity of methanolic extracts of Sambucus ebulus and Urtica dioica against clinical isolates of methicillin resistant Staphylococcus aureus. Afr. J. Tradit. Complement. Altern. Med., vol. 11, no. 5, p. 38-40. DOI: 65i11 v.ajtcam/.43141

Sethi, P. 2013. Biological characterization of the rhizome of Sansevieria roxburghiana Schult. \& Schult. f. (Agavaceae). Journal of Medicinal Plants Research, vol. 7, no. 17, p. 1201-1203. DOI: 10.5897.

Sheela D.J., Jeeva S., Shamila I.M.R., Packia Lekshmi N.C.J., Raja Brindha J. 2012. Antimicrobial activity and phytochemical analysis of Sansevieria roxburghiana leaf. Asian Journal of Plant Science and Research, vol. 2, no. 1, p. 41-44.

Staples, G.W., Herbst, D.R. 2005. A Tropical Garden Flora: Plants cultivated in the Hawaiian Island and other tropical places. Honolulu, Hawaii: Bishop Museum Press.

Takawira-Nyenya, T., Newton, L.E., Wabuyele, E., Stedje, B. 2014. Ethnobotanical uses of Sansevieria Thunb. (Asparagaceae) in Coast Province of Kenya. Ethnobotany Research and Application, vol. 12, no. 1, p. 51-69. DOI: 10.17348/era.12.0.051-069 